\title{
Development of creative orientation of future teachers based on a research approach
}

\author{
Valentina Abraukhova ${ }^{1, *}$, Tatiana Vlasova $^{1}$, Anastasia Zimovetc ${ }^{1}$ \\ ${ }^{1}$ Don State Technical University, 344000, Rostov-on-Don, Russia
}

\begin{abstract}
Transitive society makes changes in the traditional teachers training. The relevance of this issue is becoming more and more important in the light of the tendency to reduce the motivation of students to study, to obtain basic academic school knowledge. This should lead us to look for innovative approaches in the future teachers training. The article deals with the specifics of the training of future teachers in higher education and the main aim is the practical implementation of student research projects. Special attention is paid to the analysis of the professionalism of the future practice-oriented teacher and to the development of its creative orientation through a research approach to the modelling of professional activities
\end{abstract}

\section{Introduction}

Reforming the education system is a continuous process. Digital technologies are actively introduced in educational institutions. The functions of the teacher as a knowledge carrier are changing. "Living" pedagogical activity is replaced by "non-living" technologies (distance courses, tests, video lectures, and presentations). However, pedagogical activity cannot be based on certain templates, situations change - approaches change. From reproduction methods, we have moved to productive methods, clip thinking, digitalization. Changes require the teacher to increase stability and efficiency. In a transitive society, creativity becomes important as a process of generating new ideas, overcoming outdated traditions, and developing new approaches to the organization of life. The creative nature of pedagogical activity corresponds to rapidly changing living conditions. A creative teacher should see problems in a new light and avoid a stereotypical way of thinking. Such a model meets the requirements for the future teacher.

\section{Review of scientific sources}

Innovations in higher education, including pedagogical education, are developed more around management models, organizational structures and human resource management practices. The analysis reveals two groups of driving forces - a "culture of openness and freedom" and "conscious management of innovation" in universities. Emphasis is placed on the development of general competences valued by employers and the State [1]. In the USA, effective joint learning is widely used in pedagogical education - mentoring based on

\footnotetext{
${ }^{*}$ Corresponding author: childrenpalace@mail.ru
} 
five key practices: discussing differences, sharing powers, joint mentoring, coaching at the moment and immersion in practical teaching experience. Free co-education enables the professional development of mentor teachers and candidate teachers. Mentoring facilitates fluency and a variety of collaborative modes of learning [2]. In many countries, teacher education emphasizes responsible use of ICT. Most teaching students from Spain and Norway take measures to assess the digital content they find for educational purposes. The ability to evaluate digital online content has a positive relationship with perceived privacy competence [3].Simulations are increasingly used in foreign teacher education programs as a method of instruction for pre-training teachers. Simulations provide opportunities for authentic practice in a controlled environment with a reduced risk of harm. The mixed reality simulation offers strategic practice for teachers before starting work. This study has implications for the future use of mixed reality modelling for teacher training [4]. Israeli scientists consider the process of «retention» of young teachers to be important. Mentoring, support, and leadership of the school are vital to retaining aspiring teachers. [5] Many researchers give preference to the formation of the future teacher in the emotional sphere: interaction of positive emotions, self-effectiveness and job satisfaction. Teacher enthusiasm is a key factor in effective learning, favoring teacher well-being and learning behaviors, as well as students' cognitive, emotional and motivational outcomes $[6,7,8]$.Processes of formation of emotional sphere of future teacher, mentoring, joint activity of teacher and child find their development in creation - process of formation of creative potential of future teachers. The creative potential of the teacher includes a set of psychological personality qualities leading to successful pedagogical activity. In this regard, it is interesting to study the skills of interdisciplinary thinking of teachers, which are important for creativity in different disciplines. The idea of "transdisciplinary" thinking involves the formation of effective approaches to thinking and work that go beyond disciplinary boundaries. Existing studies have shown that the most successful creative thinkers in science tend to use a set of cognitive "transdisciplinary" skills at the meta-level. This set of "transdisciplinary" skills is proposed as a basis for learning for future teachers. [9] The profession of a teacher is creative in the very nature. "The continued change of team members, the changing mentality of children and their psychological and emotional state, the diversity and unpredictability of interpersonal relationship in the learning process require the teacher to be professional, flexible and creative" [10]. Creativity characterizes the ability of a person not to experience fear of the unknown, but to form his own - a unique and unique way of solving. Let us turn to the words of S.I. Hesse: "I can't say about a free person exactly how he will act, because a free person acts like no one did before him, acts in a completely new way, like no one acted before him and as soon as he can only act..." [11]. In North American literature, the study of creativity and creative abilities is almost invisible. Even in the field of education, little is said about the creative practice of teachers. However, 12 Canadian creative learning case studies conducted by the Creative Learning Research Group have been published. A detailed study of two topics is presented: the creative personality and the community. Based on the results of the study, the authors made the following conclusions: Creative training is necessary to meet the complex needs of students and society. Creative choice of teaching methods should be based on their values. In Russian literature, the psychological foundations of creative activity were widely studied (L.I. Bozhovich, D.B. Epiphany, A.A. Bodalev, L.S. Vygotsky, V.V. Davydov, I.V. Dubrovina, V.A. Slastenin and others), they identified ways to identify the essence of the realization of personality in creativity. The training of teachers for the creative development of children is devoted to the work of L.K. Veretennikova, A.E. Mozhar, V.G. Maksimov, N.M. Yakovleva. The research of Morozov A.V., Samborskaya L.N. emphasizes two components in the formation of the professionalism of the teacher [12]. This is the formation of a system of motives and the realization of encourages for creative activity. 
L.M. Mitina and E.V. Bondarchuk define the pedagogical orientation as a stable system of motives that determine the behavior of the teacher, his attitude to the profession, to his work, but first of all to the child. On the basis of research, Y.V. Bondarchuk came to the conclusion that "students-teachers should develop a business and collectivistic orientation of the personality, as well as a progressive motivational profile characterized by motives of general activity, creative activity and social utility " $[13,14]$.

\section{Methods of research}

Modern education is practical oriented. It presents new priorities: market thinking, technicality, short-clip consciousness, filled with active social meaning. The current model of education "should combine in its content traditions and innovations, aspects of humanistic education and administration, a combination of didactic and heuristic methods that reveal the completeness of cognitive and spiritual and moral principles in a person" [14] Along with the theoretical knowledge, the student should master practical skills. And this is focused on the system of practices of educational, technological, industrial and prediploma. The subject of our research is the process of development of creative orientation among students of pedagogical sphere of development. The purpose of the study is to create a pedagogical training system that forms the creative orientation of the future teacher. The basis of our research was educational institutions - beneficiaries of an educational consortium created at the Department of Theory and Methodology of Professional Education of the Don State Technical University. These institutions have become not only bases of practice, but also platforms for immersing students in real working conditions, a place for conducting research activities (Figure 1).

\section{Implementing A Research Approach To Activities}

\begin{tabular}{|c|c|c|c|}
\hline $\begin{array}{l}\text { Research } \\
\text { Programmes Based } \\
\text { On Educational } \\
\text { Institutions }\end{array}$ & $\begin{array}{l}\text { Research } \\
\text { Programmes In } \\
\text { The Preparation } \\
\text { Of Final } \\
\text { Qualification } \\
\text { Work }\end{array}$ & $\begin{array}{l}\text { Programmes Of } \\
\text { Research Practices } \\
\text { And Expeditions }\end{array}$ & $\begin{array}{l}\text { Programmes Of } \\
\text { Creative } \\
\text { Workshops And } \\
\text { Laboratories. }\end{array}$ \\
\hline
\end{tabular}

Fig. 1. Forms of implementation of the research approach to activities.

The educational consortium includes institutions of different types and kinds to show students the specifics and diversity of pedagogical activities. These are: School No. 110 named after the hero of the Soviet Union Marshal of Aviation Alexander Ivanovich Pokryshkin of the city of Rostov-on-Don, preschool educational institution "Kindergarten No. 118," Center for Assistance to Children Left without Parental Care No. 7, Center for the Development of Creativity of Children and Youth of the Pervomaysky District in Rostov-on-on-Don, Center Our study was conducted from 2017 to 2020 in the form of a three-phase experiment in order to develop the creative orientation of students. Students of courses 1, 2 and 3 were offered active work as volunteers in the above listed educational institutions. First, excursions were organized to institutions with familiarization with the specifics of their activities, then a program of joint activities of students and pupils was developed, a list of active forms of participation was compiled. A series of spiritual volunteering events, game quests, thematic creative workshops and laboratories were developed and conducted. A form of testing the effectiveness of research and creative activities of students was annual participation in scientific and practical, student conferences, "Science Week," and the Maxi-um conference. The content of work with students in spiritual volunteering, in interaction with employers, social partnership was 
repeatedly reflected in the publications of the authors $[15,16,17]$. To study the conditions for the development of the creative orientation of future teachers, diagnostics were used to track the criterion parameters of the creative orientation. A phased questionnaire, conducted with a permanent composition of respondents ( 50 people - future kindergarten teachers and computer science teachers) was held at the beginning of the school year in September and at the end of the year - in May.

Stage I - Diagnostics of Creative Education (CE) Level of Students

2017, September

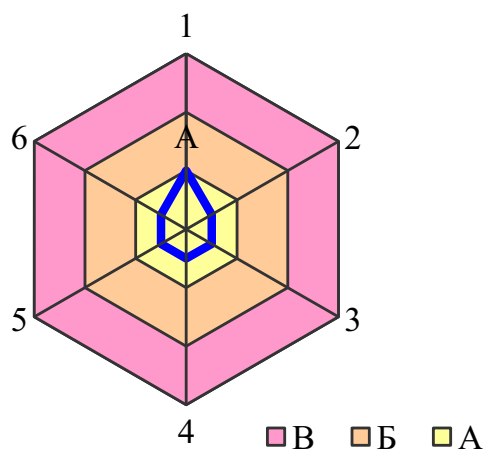

2018, May

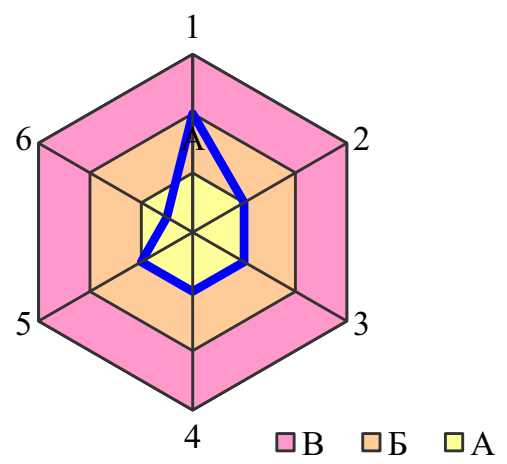

Characteristics of COP(creative oriented person): 1 - enthusiasm; 2 - organization; 3 - determination $\backslash$ dedication;

4 - integrativity; 5 - innovative approach; 6 - leadership.
Levels of COP:
A - knowledge;
Б - perception;
$\mathrm{B}-$ action.

Fig. 2. Diagnosis of the level of formation of creative orientation. 2017-2018.

Stage II - Diagnosis of the level of formation of creative orientation (CO)

2018, September

1

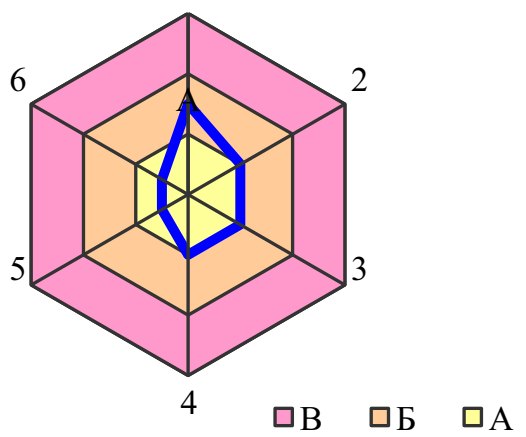

2019, May

1

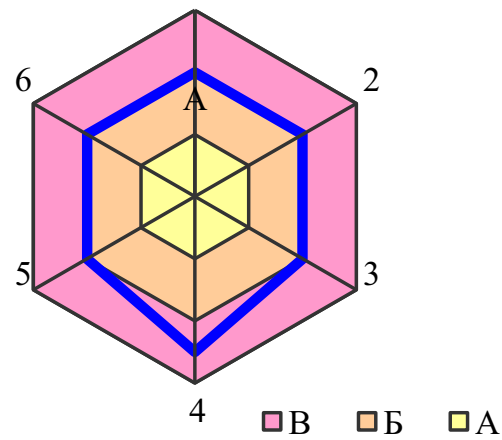

Characteristics of COP: 1 - enthusiasm; 2 - organization; 3 - determination $\backslash$ dedication; 4 - integrativity; 5 - innovative approach; 6 - leadership.

Levels of COP: $\quad \mathrm{A}$ - knowledge; $\mathrm{B}$ - perception; $\mathrm{B}$ - action.

Fig. 3. Diagnosis of the level of formation of creative orientation. 2018-2019.

To determine the formation of the creative orientation of future teachers, two key criteria for the formation of the creative orientation were chosen: personality-competent (enthusiasm, organization, determination to ensure creative self-realization) and social and communication (integrativity, innovative and leadership position). A special place among 
the criteria of the creative orientation of the individual is occupied by an innovative position - the desire to make his own contribution to a particular business that exceeds the scope of the requirements [18]. The results of the experiment are reflected in hexograms 13.

Stage III - Diagnostics of Creative Education (CO) Level of Students
$\begin{array}{ll}\text { 2019, September } & \text { 2020, May }\end{array}$

1

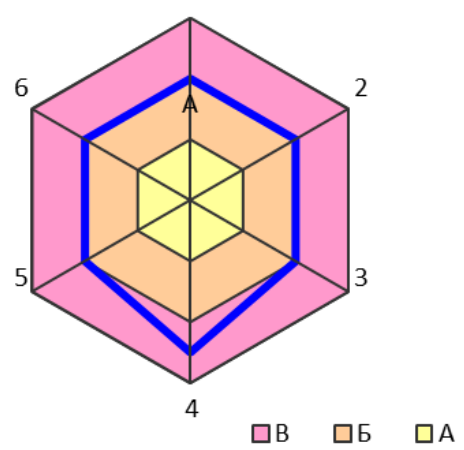

1

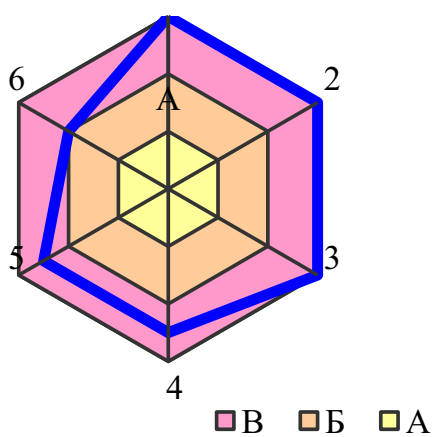

Characteristics of COP: 1 - enthusiasm; 2 - organization; 3 - determination $\backslash$ dedication; 4 - integrativity ; 5 - innovative approach; 6 - leadership.

Levels of COP: A-knowledge; $\quad \mathrm{B}$-perception; $\mathrm{B}$ - action

Fig. 4. Diagnosis of the level of formation of creative orientation. 2019-2020.

The study showed that as students immerse themselves in active, practical-oriented forms of work, theoretical and practical knowledge and skills are actively mastered, communication skills are expanded, barriers are overcome. Each student is revealed in the activity. There is no direct dependence on the student's academic progress and his creative activity.

\section{Results and discussion}

In the journal of the World Economic Forum, creativity as a quality of personality is on the second place in a number of future workers cognitive abilities. It is no coincidence that many innovations appear in models of pedagogical education based on the development of critical thinking, the formation of non-standard thinking, the application of social design methods, and immersion in real production situations. The result of this study was the development of diagnostic methods for the development of the creative orientation of the personality of the future teacher.

Our study confirmed that every person goes through a path of creative development. The desire to create is based on an interest in his future profession.

Creative activity naturally attracts the attention of others, and the results of this activity should be the subject of pride, as an original, new product is created. Public evaluation is very important, which leads to an increase in self-esteem. Creative activity should be supported by others.

The final diagnosis of students of the 3rd year showed: the main reasons for attending events within the framework of the educational consortium were interest in obtaining new knowledge and skills (88\%), the opportunity to realize their abilities and skills $(77 \%)$, classes help prepare for the development of other disciplines in the profile - $(38 \%)$. When answering the question "What did you learn in classes, events held on the basis of 
educational institutions": most - students (83\%) answered that they received certain knowledge, skills and skills in the profile of the future profession, $10 \%$ developed their personal qualities. And 12\% answered unspecified: they learned a lot, good, everything. This may indicate low reflexive ability, as well as external motivation to attend classes. According to $89 \%$, the knowledge and skills gained during the preparation and conduct of events will be useful to them: in life in general, including in the future $(36 \%)$, in the future profession and work $(23 \%)$, in communication with people $(16 \%)$, to participate in competitions, conferences, various performances $(25 \%)$. Future teachers believe that active forms of holding events within the framework of the educational consortium have influenced the development of the following qualities of their personality: self-confidence (34 people - 28\%); sociability, communication skills (27 people - 22\%); friendliness, openness, freedom(18 people - 15\%); patience, perseverance, self-control (19 people $16 \%)$; development of creative abilities (10 people - 8\%); hard work, working capacity (9 people - 7\%); mindfulness ( 9 people - 7\%), erudition, curiosity ( 9 people - 7\%), ability to work in a team (6 people $-5 \%)$, responsibility, independence (6 people $-5 \%)$.

\section{Conclusions}

If we consider the development of the creative orientation of future teachers as a system for the formation of life values, then the system of value orientations is a reflection of the attitude to the surrounding reality, an indicator of the stability of society, being also part of the spiritual sphere, a manifestation of social creativity [19].

The creative orientation is an important element of the personality structure of the future teacher, which characterizes the internal readiness to master knowledge and learning technologies.

The results of the experiment show that the development of the creative orientation of future teachers can be ensured if universities, working in an innovative mode, create an organizational and pedagogical system of interaction with relevant organizations and institutions.

The undertaken research shows that the development of a creative orientation is a prerequisite in the preparation of the future teacher.

\section{References}

1. A. Lašáková, L. Bajzíková, I. Dedze, International Journal of Educational Development 55, 69-79 (2017) https://doi.org/10.1016/j.ijedudev.2017.06.002

2. M. Thompson, A. Schademan, Teaching and Teacher Education 86 (2019) https://doi.org/10.1016/j.tate.2019.102903

3. G.B. Gudmundsdottir, H.H. Gassó, J.C.C. Rubio, O.E. Hatlevik, Computers \& Education 152 (2020) https://doi.org/10.1016/j.compedu.2020.103877

4. T. Dalinger, K.B. Stansberry, S.Y Xiu, Computers \& Education 144, 103696 (2020) https://doi.org/10.1016/j.compedu.2019.103696

5. E. Zavelevsky, O.S. Lishchinsky, Teaching and Teacher Education 88 (2020) https://doi.org/10.1016/j.tate.2019.102965

6. A.E. Berikkhanova, Zh.A. Zhussupova, G.Ye. Berikkhanovac, Procedia - Social and Behavioral Sciences 171, 1142-1146 https://cyberleninka.org/article/n/1336361/viewer

7. I. Burić, A. Moè, Teaching and Teacher Education 89, 103008 (2020) https://doi.org/10.1016/j.tate.2019.103008 
8. J. Choi, J.-H. Lee, B. Kim, Teaching and Teacher Education 85, 45-57 (2019) https://doi.org/10.1016/j.tate.2019.05.005

9. D. Henriksen, Journal - Thinking Skills and Creativity 22, 212-232 (2016) https://doi.org/10.1016/j.tsc.2016.10.007

10. O.M. Shevtsova, S.V. Bulycheva, Problems of modern pedagogical education 64(2) (2019) https://cyberleninka.ru/article/n/professionalizm-pedagoga-praktika-kakneotemlemyy-obrazovatelnyy-resurs-v-podgotovke-spetsialistov-tvorcheskoy

11. S.I. Hessen, Fundamentals of pedagogy. Introduction to Applied Philosophy (School Press, M., 1995)

12. A.V. Morozov, L.N. Samborskaya, Kazan Pedagogical Journal 6, 43-48 (2018)

13. E.V. Bondarchuk, Sananyev readings. Series: Psychology of Education in the Modern World 171, 1142-1146 (2015) https://doi.org/10.1016/j.sbspro.2015.01.222

14. V.A. Lezier, Mat. III All-Russian Scientific and Practical Conference "North of Russia: Strategies and Prospects for Development" (Surgut, 2017)

15. V.V. Abraukhova, Liturgical practices and cult arts in the modern world: sb. Materials International. conf. (2018)

16. T. Vlasova, E. Krasnova, V. Abraukhova, N. Safontseva, JofSStER 9(1), 76-88 (2018)

17. T.I. Vlasova, V.V. Abraukhova, NESR:NMiT, 17-21 (2018)

18. V.V. Abraukhova, Formation of the creative orientation of the personality of pupils of institutions of additional education (Foundation, Rostov n/D, 2011)

19. E.N. Fedorova, E.V. Ptitsyna, Basic research 2(2), 401-405 (2015) 